Posted with permission from the Annual Review of Linguistics, Volume 7 (c) by Annual Reviews, http://www.annualreviews.org. This version downloaded from SOAS Research Online:

Pre-print version; May 2020 http://eprints.soas.ac.uk/34858

Published Jan 2021 in Annual Review of Linguistics

10.1146/annurev-linguistics-031920-115317

\begin{abstract}
In a serial verb construction (SVC), two or more verbs combine in a single clause without any morphosyntactic marking of linking or subordination. However, the way this description is interpreted and diagnosed by different linguists is a continual source of controversy. There are often different assumptions about the nature of verbhood and clausehood, as well as disagreements over how to interpret morphosyntactic marking in particular languages. Despite the fuzzy nature of the category, SVCs are commonly found to have similar functions in many languages, for example, expressing closely linked sequences of events, directional and prior motion, concurrent aspects of a single event such as posture alongside another activity, as well as being used to express particular semantic roles or to express aspectual meaning. The morphosyntactic complexity and diversity found in SVCs continues to challenge conceptions of the clause assumed in both generative and comparative approaches to syntax.
\end{abstract}




\title{
Serial verb constructions
}

\author{
Joseph Lovestrand
}

May 8, 2020

\section{Contents}

1 INTRODUCTION 3

2 MORPHOSYNTAX OF SVCS 6

2.1 Verbhood ...................... 6

2.1 .1 Verb-verb compounds $\ldots \ldots \ldots \ldots \ldots$

2.1.2 Morphosyntactic criteria . . . . . . . . . . . 7

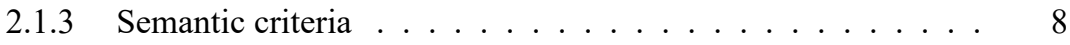

2.2 Clausehood . . . . . . . . . . . . . . . . 10

2.2 .1 Negation $\ldots \ldots \ldots \ldots \ldots \ldots \ldots \ldots \ldots \ldots$

2.2 .2 Tense-aspect $\ldots \ldots \ldots \ldots \ldots \ldots$

2.2.3 Argument structure . . . . . . . . . . . . . . . . . . 14

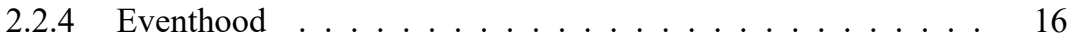

2.3 Linking or subordinating marking $\ldots \ldots \ldots \ldots \ldots$

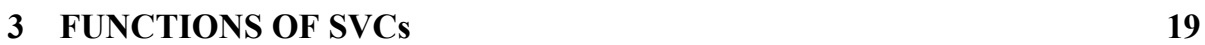

3.1 Symmetrical . . . . . . . . . . . . . . . . . . . . . 20

3.2 Motion . . . . . . . . . . . . . . . . . . . . 21

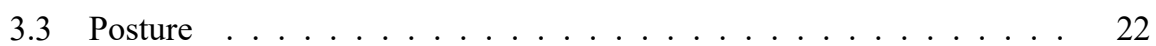


3.4 Valency-changing ......................... 22

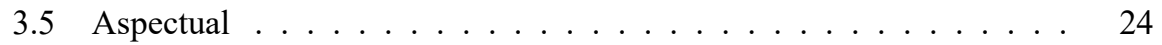

4 SVCS IN GENERATIVE SYNTAX 25

5 SVCS IN COMPARATIVE SYNTAX 27

6 CONCLUSION 29

\section{INTRODUCTION}

Serial verb constructions (SVCs) are when two or more verbs can be said to be in the same clause, but not morphosyntactically marked for coordination, subordination or complementation (e.g. Aikhenvald and Dixon 2006; Durie 1997; Foley and Olson 1985; Lord 1993; Sebba 1987). However, linguists do not agree how to interpret any of the three parts of this description of SVCs. What counts as a verb in a putative multiverb construction? How is clausehood defined and diagnosed? What is the significance of a particular morphosyntactic marker in a given language? The absence of a shared set of cross-linguistically valid diagnoses for these concepts results in controversy permeating the literature on SVCs.

Historically, the term SVC emerged as a "pretheoretical umbrella term" for a "class of phenomena that are in some way problematic in theorizing" (Zwicky 1990). The earliest relevant literature is on languages of Ghana, in particular Akan. ${ }^{1}$ Various labels were used for similar constructions in languages of West Africa and Southeast Asia until a gradual consensus on the terminology of serialization was reached in the 1970s (e.g. Bamgboṣe 1974; George 1975; Hyman 1971; Li and Thompson 1973; Stahlke 1970). ${ }^{2}$

\footnotetext{
${ }^{1}$ Akan is considered either a cluster of dialects or a macrolanguage, and early publications frequently use the name of one of the two major varieties: Twi and Fante. Christaller (1875:144-145) is often cited as the first documentation of SVCs in Akan, but this work was influenced by Riis (1853 in German; English version: 1854:26-30, 103-104) on Akan and by Zimmermann (1858:45-49, 56-57) on Ga.

${ }^{2}$ A short article on Akan by Stewart (1963) is sometimes cited as the first to identify SVCs or the first to coin the term, however, the label "serial verbs" can be traced back to Balmer and Grant's (1929:117) study
} 
Numerous publications on SVCs begin to appear around the 1980s for Austronesian languages (e.g. Bradshaw 1982; Crowley 1987; Durie 1988), Papuan languages (e.g. Bruce 1988; Foley and Olson 1985) and Creoles (e.g. Baxter 1988; Jansen et al. 1978; Sebba 1987). ${ }^{3}$ Around the 1990s, SVCs first appear in descriptions of Australian languages (e.g. Evans 1995; Goddard 1988; Green 1995) and South American languages (e.g. Aikhenvald 1999; Hale 1991), and, more recently, in publications on sign languages (e.g. Benedicto et al. 2008; Bos 2016; Couvee and Pfau 2018; Supalla 1990).

Seuren (1990:15) critiques the historical development of the literature on SVCs as the result of the "Me Too Principle": "No sooner had the term been introduced than serial verb constructions were spotted left, right and center..." There is a sense in which serialization emerged as a category of typological leftovers. "A working definition would sometimes seem to be any such series [of verbs] not found in the common European languages" (Bendix 1972:3) However, Bradshaw (1993:158) has a more positive perspective: "As more and more languages are examined for evidence of verb serialization, more and more varieties of the phenomenon have turned up."

Despite the fuzzy nature of the category, various definitions of SVCs tend to identify predominantly overlapping sets of constructions. Using one particular definition of SVCs, Ross (2020) finds evidence of SVCs in 124 languages out of a sample of 325 languages. SVCs are not restricted to any particular part of the world, but they are more commonly found in the languages of West Africa, Southeast Asia and the Pacific. Overviews of SVCs in particular parts of the world have been done for parts of West Africa (George 1975; Shluinsky 2017; Stahlke 1970), the Pacific (Bril and Ozanne-Rivierre 2004; Crowley 2002) and Southeast Asia (Bisang 1991; van Staden and Reesink 2008; Unterladstetter 2020), as well as for Creole languages (Jansen et al. 1978; Muysken and Veenstra 2006).

Examples 1 through 5 exemplify some of the genetic diversity of languages in which

of Akan, as well as a reference to "series of verbs" by Welmers (1946:63)

${ }^{3}$ A notable early publication on SVCs outside of Africa is a description of Reihensatz 'serial sentences' in the Austronesian language Yabem by Dempwolff (1939 in German; English version: 2005). 
SVCs are found, as well as some of the meanings that are commonly expressed in SVCs. ${ }^{4}$

Sequential SVC (Section 3.1) in Ewe (Niger-Congo)

(1) Áma ku te da du Ama dig yam cook eat

Ama dug up yams, cooked [them, and] ate [them]. (Ameka 2001:14)

Prior motion SVC (Section 3.2) in Arapesh (Papuan)

\section{(2) W-u-nak w-i-chúlokuh}

3PL.F.SBJ-IRR-go 3PL.F.SBJ-IRR-wash

They will go [and] wash. (Conrad and Wogiga 1991:56)

Directional SVC (Section 3.2) in Vitu (Oceanic)

(3) pale hadora ia raga zahe kara hud-a hai so cuscus 3sg jump go.up to top-3sg tree

So the cuscus jumped up into the tree. (Van den Berg and Bachet 2006:177)

Instrumental SVC (Section 3.4) in Thai (Tai-Kadai)

(4) sùk cháy phráa khôon tônmáy

Sook use machete cut tree

Sook chopped down the tree with a machete. (Filbeck 1975:120)

Aspectual SVC (Section 3.5) in Gurr-goni (Non-Pama-Nyungan)

(5) njibu-wu-ni njiwurr-ni- $\varnothing$ mi:lk

1PL.ERG.3SG.ACC-give-REAL 1PL.ERG-Sit-REAL milk.DUR

We were giving her milk for such a long time.(Green 1995:38)

Section 2 outlines the primary criteria that have been used in the many different definitions of SVCs. Section 3 highlights a few of the most common meanings that are expressed in SVCs. Section 4 briefly discusses the basic approaches to SVCs in

\footnotetext{
${ }^{4}$ Examples follow the Leipzig Glossing Rules. The verbs that make up an SVC are in bold. Abbreviations: 1 first person, 2 second person, 3 third person, ACC accusative, CM class marker, DEF definite, DET determiner, DU dual, DUR durative, ERG ergative, EXCL exclusive, F feminine, FOC focus, FUT future, GEN genitive, IMM immediate, INCL inclusive, IPFV imperfective, IRR irrealis, NEG negation, NOM nominative, PL plural, PRF perfect, PST past, REAL realis, REM.PST remote past, SBJ subject, SG singular.
} 
generative syntax, and Section 5 addresses the challenge of SVCs from the perspective of comparative syntax. Section 6 is a brief conclusion. As a condensed review of current issues for descriptive, generative and typological approaches to SVCs, there are relatively few illustrative examples provided in this article. For a broad overview of examples of SVCs from languages spoken all over the world, see Aikhenvald (2006b, 2018).

\section{MORPHOSYNTAX OF SVCs}

SVCs are typically defined in morphosyntactic terms: multiple verbs (Section 2.1), single clause (Section 2.2), and no morphosyntactic linker or subordinator (Section 2.3). However, linguists' assumptions about these grammatical concepts do not resolve into a single set of diagnostic criteria. In some cases, the differences are merely terminological or are disputes over how to analyze a particular language. However, some of the differences, especially over how to define and diagnose monoclausality, point to more profound gaps in our conceptualization of syntax.

\subsection{Verbhood}

There are at least three issues related to how to define what counts as a verb in an SVC. First, there are different assumptions about whether two verb roots in a single morphosyntactic word should be counted as one verb or two (Section 2.1.1). Second, it is not always clear, even in language-specific terms, how to distinguish verbs from other lexical categories (Section 2.1.2). Finally, there is disagreement over whether a verb that expresses grammatical meaning (as opposed to lexical meaning) in a multiverb construction should be considered an SVC (Section 2.1.3). 


\subsubsection{Verb-verb compounds}

The most obvious issue in regards to verbhood in SVCs is whether two verb roots that make up a single morphosyntactic word should count as two verbs or just one. ${ }^{5}$ Lord (1975) demonstrates that there are functional similarities between "verb compounds" in Igbo, where multiple verb stems form a single morphosyntactic word, and SVCs in other languages, where the verb stems are separate morphosyntactic words. However, she distinguishes verb-verb compounds and SVCs as separate categories. Many linguists continue to restrict SVCs to cases of where the verb roots form two distinct morphosyntactic words (e.g. Crowley 2002:13-14; Déchaine 1993:809; Guillaume 2013).

The categorical distinction between verb-verb compounds and SVCs was challenged by Foley and Olson (1985:22) who used examples of two verb roots forming one morphosyntactic word as an argument for monoclausity of SVCs: "A simple but compelling argument for the mono-clausal hypothesis is that in some languages such as Igbo... serial verb constructions are grammatically one word." Others have followed suit, viewing verb-verb compounds as a case of more than one verb (root), and therefore a type of SVC (e.g. Aikhenvald 2006b; Durie 1997; Nishiyama 1998). In a sense, the view that verb-verb compounds count as a type of SVC is an expanded view compared to earlier publications. However, it is also a legitimate matter of ambiguity as to what counts as a verb. To avoid confusion, descriptions and definitions of SVCs need to clarify where they stand on this issue. ${ }^{6}$

\subsubsection{Morphosyntactic criteria}

The lexical category of verb in the SVC literature is generally treated as a languagespecific lexical category, normally defined morphologically. However, there are some

\footnotetext{
${ }^{5}$ Ignoring, for the sake of discussion, controversies around the validity of a distinction between phonological and morphosyntactic words (Tallman 2020).

${ }^{6}$ This article focuses on SVCs where the verbs form separate morphosyntactic words, but includes one verb-verb compound in example 11 below. For the sake of this paper, verb-verb compounds can be thought of as a less-prototypical type of SVC (Section 5).
} 
cases where morphological criteria do not distinguish verbs from other lexical categories. Westermann (1930:129-130) realized early on that a lack of inflectional marking can create ambiguity between verbs and prepositions (see also Ansre 1966). Similar issues were identified in Mandarin under the label "co-verbs" by Li and Thompson (1974). Durie (1988) presents a typology of "verbal-prepositions" in Oceanic languages. In the absence of distinctive verbal morphology, patterns of syntactic distribution have been used to distinguish verbs and prepositions (e.g. Jansen et al. 1978; Li and Thompson 1974; Lord 1973).

Another syntactic issue for defining verbhood is whether a putative verb is "capable of appearing as the only verb in a simple sentence" (Sebba 1987:39). In example 6a, the word $f i$ 'use' in Yoruba occurs in what is typically referred to as an instrumental SVC (Section 3.4), but this word cannot be used on its own as the main verb of an independent clause (example 6b). The same is true of the word de 'take' in Akan (Campbell 1996:86, 92).

Yoruba (Niger-Congo)

(6) a. Mo fi ọ̀be ge bùrédì I USE knife cut bread I cut the bread with a knife.

b. * Mo fi òbe

I USE knife

for: I used/took a knife. (Carstens 2002:24)

Guillaume (2013:24-25) criticizes the use of the label SVC in cases like these as a failure to distinguish synchronic and diachronic analyses. From a diachronic perspective, it is not surprising that a verb occurring in an SVC might grammaticalize into some other lexical category, and lose its ability to occur on its own outside an SVC (Bowern 2008). Although the construction in example 6 has long been labeled an SVC, this is a potentially misleading label as the construction is apparently not composed of two verbs, but of a single verb and a particle or other lexical category. 


\subsubsection{Semantic criteria}

Another issue is whether verbs should be defined by morphosyntactic criteria alone, or if additional semantic restrictions should be placed on the category. In many cases, a single form has two different meanings according to the context: predicating an event when used on its own as the main verb of a clause, and expressing an abstract grammatical meaning when combined in a clause with another verb. For example, the Yoruba verb $l o$ ' $g o$ ' in example 7a contributes a motion meaning in an independent clause with its own subject pronoun and TAM prefix, but in the SVC in example $7 \mathrm{~b}$ it appears in a bare form and contributes an aspectual meaning (Section 3.5).

Yoruba (Niger-Congo)

(7) a. ó ń-sùn; ó ń-lọ he IPFV-sleep he IPFV-go

He is sleeping and going.

b. ó ń-sùn lọ he IPFV-sleep go

He is falling asleep. (Bamgboṣe 1974:31-32)

In descriptive and typological publications, SVCs normally include those cases where one of the verbs would indisputably be said to have a different meaning from the same verb form used on its own, as in the aspectual SVC in example 7b. For example, Aikhenvald (2006b:22) states: “A grammaticalized 'minor' verb [in an SVC] can still retain full lexical status in the language outside the constructions in which it has been grammaticalized."

On the other hand, Foley and Olson (1985:210) do not recognize aspectual SVCs as a legitimate type of SVC, and instead describe such constructions as: "an aspectual operator realized by a verb stem and a predicate within its scope." Others have adopted a similar restrictive semantic criterion to disallow the category of aspectual SVCs, motivated either by a theory of comparative syntax (Anderson 2006:144; Haspelmath 
2016:302) or by a generative model of syntax where only argument-sharing SVCs are considered the proper object of analysis (Section 4). However, it is not always clear where to draw the line between what is and is not a case of grammaticalized semantics (Enfield 2009). Another challenge is that there are many cases of ambiguity between an aspectual and non-aspectual interpretation of the same construction, as in example 8 (see also Bamgboșe (1974:34) and Green (1995:278)).

\section{Ewe (Niger-Congo)}

(8) Kofi va kpo novi-a

Kofi come see sibling-DEF

Kofi came and saw his sibling.

or Kofi eventually saw his sibling. (Essegbey 2004:474)

The proposed semantic restriction on verbhood in SVCs is not typically applied in descriptive studies, and it is not always practical to diagnose. Therefore, it seems reasonable to continue describing multiverb constructions with aspectual meaning as SVCs, provided that the verb that has grammaticalized meaning retains the morphosyntactic features of a verb (Section 2.1.2). However, descriptions of SVCs should give special attention to possible semantic differences between a verb used in an SVC and the same form used on its own as the main verb of a clause, with the understanding that these semantic differences have significant implications for both comparative and generative syntax.

\subsection{Clausehood}

The notion of clausehood is the most significant underlying conceptual challenge in the study of SVCs. There may have once been an assumption "tacitly accepted among grammarians as a working hypothesis... that the grammatical level of the clause is roughly coterminous with the number of predicates in a given sentence" (Foley and Olson 1985:17). Now syntacticians presumably agree that "in linguistic theory, we must 
deny any isometric relation between the clause and the predicate" (Foley and Olson 1985:32). Although the simplistic one-verb-equals-one-clause hypothesis has been debunked, no widely-accepted definition of clausehood has arisen to take its place. There is no general consensus on how to diagnose clausehood cross-linguistically in empirical terms, which raises the question of whether what is claimed to be a single clause in one language is the same thing as a single clause in another language (Section 5).

This section looks at four issues commonly discussed in regards to the monoclausal nature of SVCs: negation (Section 2.2.1), tense-aspect marking (Section 2.2.2), argument structure (2.2.3) and eventhood (Section 2.2.4). The first three can be taken to be sufficient but not necessary criteria for monoclausality, while eventhood is perhaps necessary (at least in some cases) but not sufficient for establishing monoclausality. The multiple approaches to defining and describing clausehood allow for flexibility in language-specific descriptions. The linguist can apply whatever criteria are relevant to the language under discussion, but, in the ideal case, all possible methods of testing clausehood would be applied. Using more than one criterion creates a richer data set to inform generative and comparative studies of SVCs.

\subsubsection{Negation}

SVCs are often said not to allow their verbs to be independently negated. This would be a surprising feature if the construction contained two clauses. For example, Baird (2008:57) applies this criterion to Keo, giving the sentence in example 9, and stating, "A negator has scope over the entire serial verb complex... If only one or other of the verbs... were to be negated then the intonation contour over the two verbs would be broken," indicating a juxtaposition of two independent clauses rather than an SVC.

Keo (Austronesian)

(9) Nga'o mona demba moni 'imu-ko'o

1SG NEG come watch 3PL

I didn't come and watch them. (Baird 2008:57) 
In some cases, the interpretation of negation is an effective way to distinguish SVCs from the juxtaposition of independent clauses. However, since it is well known that many languages allow a single constituent of a clause to be negated, it is not the case that narrow scope of negation over one verb in an SVC necessarily rules out a monoclausal analysis. For this reason, the restriction on negation is sometimes described as a distributional restriction on the number of negation markers allowed structurally, but with the possibility of different scope interpretations. Banjo (1974) demonstrates that the second verb in a serial verb construction in Yoruba cannot be structurally negated by placing a negator between the verbs, but recognizes the potential for ambiguous scoping of a negation marker before the first verb, giving two possible interpretations of example 10 .

\section{Yoruba (Niger-Congo)}

\section{(10) Ade kò dìde kọrin}

Ade NEG stand sing

Ade did not stand up and sing/sing standing. or

Ade did sing but did not do so standing. (Banjo 1974:44-45)

A remarkable example of narrow scope of negation within a putative single clause is from Alamblak, where several verb roots form a single morphosyntactic word (i.e. verbverb compound or one-word SVC), yet the scope of negation is ambiguous. If scope of negation were generalized as a universal test of clausehood, example 11 would be a case of multiple clauses within a single morphosyntactic word.

\section{Alamblak (Sepik)}

(11) ritm fiñji tandhi-ak-ni-r-më-t-m insects NEG roast-get-go-IRR-REM.PST-3sG.F-3PL

She did not roast (and) get the insects and go. or She took them unroasted.

or She roasted the insects and went having left them (did not take them). 
or She roasted and got the insects but did not go.

or She left them uncooked and went.

or She roasted them, didn't take them and didn't go. (Bruce 1988:27)

In summary, there are two basic approaches to understanding the restriction on negation: as a distributional restriction on negation marking or as a semantic restriction on the scope of negation (Lambert-Brétière 2010). The latter is a narrower view since a single scope of negation in a construction implies that there will be only one negation marker (with the exception of concordant inflectional marking and discontinuous marking). However, since negation properties vary from language to language, the inability to negate a single verb in an SVC should be taken as a sufficient, but not a necessary criterion of monoclausality.

\subsubsection{Tense-aspect}

As a single clause, it is often said that an SVC can have only one value for tense, aspect and mood (TAM). Ross (2020) points out that there are at least three ways that morphosyntactic marking can show up in SVCs. The marking can be "agreeing" where identical marking is found on each verb (e.g. the realis marking in example 12). It can be "sharing" where marking is found on only one verb, and the other verb is in a bare or unmarked form (e.g. the future marking in example 13). Or the construction can be "isolating" where there is no morphosyntactic marking on the verbs (as in example 8 above).

Paamese (Oceanic)

(12) kai ngan kumal dal tinvīs 3SG 3SG.REAL.eat sweet.potato 3SG.REAL.be.with tinned.fish

He ate sweet potato with tinned fish. (lit., He ate sweet potato; it was with tinned fish.) (Crowley 1987:50)

Ewe (Niger-Congo) 
(13) me a fo kadegbe gba

I FUT hit lamp break

I will hit the lamp and break it. (Collins 1997:463)

However, there are also cases of different TAM marking on each verb in an SVC. The first linguist to mention that the verbs in an SVC share identical TAM marking was also the first to clarify that there are some principled exceptions to the rule in Ewe: "All consecutive verbs are of the same tense or mood. But the ingressive is used for main verbs only, and in this case the following verbs are in the future" (Westermann 1907, 1930:126). In a similar manner, Crowley (1987:44) describes serial verb constructions in Paamese where some inflections can only occur on the first verb, and not on the second verb. In example 14, a realis verb is followed by a verb in the "immediate mood". Crowley (1987:44) analyzes the mismatch as a type of reduced concordant marking where the second verb is less specific than the first (see also Ameka 2005:6 and Lovestrand 2018:98-102).

\section{Paamese (Oceanic)}

(14) kaile a-ro-muasi-tei vuasi voo-mate

3PL 3PL-REAL-NEG-hit-NEG pig 3SG-IMM-die

They didn't kill the pig by hitting it. (Crowley 1987:45-46)

These examples are unproblematic if it is clarified that the tense-aspect criterion for SVCs refers to the overall meaning of the construction. A single TAM meaning can be composed of different but compatible TAM marking on the verbs in an SVC. However, if two verbs in a multiverb construction each have their own independent TAM meaning, the construction would not normally be considered an SVC. It can be questioned whether the restriction on TAM in SVCs is a traditional descriptive criterion, or a diagnostic for clausehood. One argument against TAM as a diagnostic for clausehood is the case of nominal tense, a phenomenon that allows multiple independent TAM meanings in a single clause (Nordlinger and Sadler 2004). If TAM meaning has a role in defining clausehood, it is a sufficient criterion, but not a necessary one. 


\subsubsection{Argument structure}

Another possible indicator of the monoclausal status of SVCs is shared arguments. Two common patterns of argument sharing are frequently mentioned in the literature. Sebba (1987:86-87) states: “...serial verb constructions have at least the following properties: Either: the semantic subject of $\mathrm{V}_{i}$ [the first verb of a two-verb SVC] is the semantic subject of $\mathrm{V}_{i}+1$ [the second verb], or: the object of $\mathrm{V}_{i}$ is the semantic subject of $\mathrm{V}_{i}+1$." These two patterns, "same subject" and "switch subject", have remained the predominately recognized patterns in SVCs (e.g. Aikhenvald 2006b; Bradshaw 1993; Durie 1997; Foley and Olson 1985). However, a few linguists have restricted the concept of SVCs to either the subject-sharing type (Ameka 2001; Welmers 1973:367) or a version of the switch-subject type called "object sharing” (Baker 1989; Collins 1997).

Besides the two most common patterns of argument sharing, there are other ways that the arguments of the verbs of an SVC might relate to each other. One common type is instrumental SVCs (Section 3.4), as in example 15. In this example, the verbs share their subject, and each verb has its own object/patient. In addition, the object of the verb teki 'take' must have the semantic role of instrument in the action predicated by the main verb, bron 'burn'. Note that it is not possible for the objects to be co-referential, even when the second is a pronoun.

\section{Sranan (Creole)}

(15) Kofi teki a swafru bron en Kofi take the match burn it

Kofi burns it with a match. (not Kofi takes a match and burns it.) (Sebba $1987: 132)$

There are several less common patterns of argument sharing attested in SVCs. For example, Crowley (1987:48) notes a case of "cumulative subject" in Paamese (example 16) where the subject prefix on the second verb has a split antecedent referring to both the subject and the object of the first verb. In other languages, similar constructions 
with the same meaning have no pronominal element on the second verb, exhibiting a type of split control pattern (Landau 2000).

\section{Paamese (Oceanic)}

\section{(16) ma-kuri-ko lo-va-haa}

1SG.IMM-take-2sG 1DU.INCL-IMM-go

I will take you away with me. (lit., I take you we (dual) go) (Crowley 1987:48)

Despite the generalization that serialization involves verbs that share arguments, there are cases where the verbs do not seem to share any arguments, at least not in the sense of semantic roles. One such pattern is when the entire event or state of affairs described by one verb is the argument of the other verb. These are labeled "ambient" serialization by Crowley (1987:40). Note that in example 17 the second verb has a third person singular subject marker which cannot be co-referential with any of the arguments of the first verb. The pronominal referent appears to be the Davidsonian event of the first verb (Davidson 1967).

Numbami (Oceanic)

(17) ma-pisa ai i-iye taun 1PL.EXCL-find 3PL 3SG-lie town

We found them in town. (lit., We found them; it was in town.) (Bradshaw 1993:154)

François (2006) gives an example of a particularly interesting type of SVC in Mwotlap with no apparent argument sharing. Both verbs in example 18 are intransitive verbs. Each verb contributes its one argument to the resulting transitive construction expressing "low agency causation". The events of each verb are semantically linked by a cause-effect relationship, but the argument structures of the verbs are not directly linked. Nonetheless, the argument of the second verb is expressed as an object, rather than as another subject, as might be expected. 


\section{Mwotlap (Oceanic)}

(18) ne-lē̄ mi-yip hal-yak na-kat DEF-wind PRF-blow fly-away DEF-cards

The wind blew the cards away. (François 2006:232)

Argument sharing is often included as a criterion in definitions of SVCs, but these constructions from Oceanic languages give reason to reconsider whether argument sharing should be considered a necessary criterion of monoclausality. At very least, it is clear that SVCs are not limited to the relatively common cases of subject and object control. In many cases, SVCs are limited to a single set of arguments (e.g. only one agent, only one patient), and this pattern could be interpreted as evidence of a single (complex) predicate, and therefore a single clause. However, it does not necessarily follow that all monoclausal constructions are necessarily restricted to a single set of arguments.

\subsubsection{Eventhood}

The morphosyntactic patterns associated with monoclausality are sometimes claimed to be a grammatical expression of a single-event conceptualization. For example, Bradshaw (1982:28) cites a claim by Lord (1973:269) that SVCs refer to a single event, then goes on to say: "Of course, this semantic unity has syntactic consequences" including that the verbs of an SVC "may not contrast with regard to negativity, tense, mood, or illocutionary force." Bisang (2009:805) speculates that a "closer look across these areas may well reveal that the only common property shared by all the languages that have SVCs is eventhood in the sense that an SVC as a whole covers one single event." Others find the notion of eventhood too subjective to diagnose (e.g. Comrie 1995:36; Foley 2008; Haspelmath 2016:306).

Bisang (2009:793) defines eventhood in SVCs in terms of the semantic tests proposed by Bohnemeyer et al. (2007:497) which they call the "macro-event property" or MEP: "A construction has the MEP if temporal operations such as time adverbials, 
temporal clauses, and tenses necessarily have scope over all subevents encoded by the construction." Note that in terms of diagnostics, this overlaps with the restriction on TAM in SVCs (Section 2.2.2). Other approaches to diagnosing eventhood in SVCs have gone away from relying on morphosyntactic properties to examining intonational boundaries (Givón 1991), analyzing co-speech gestures (Defina 2016) and implementing psycholinguistic experimentation (Cole 2016; Defina and Majid 2012).

In some descriptions, eventhood in SVCs is treated as a culturally- or pragmaticallyconditioned restriction on the productivity of SVCs. The explanation Jarkey (1991) gives for the unacceptability of the Hmong SVC in example $19 \mathrm{~b}$ is that dancing and listening are normally viewed in the culture as two distinct events, whereas the SVC in example 19a represents a culturally salient event where those who play the bamboo pipe also dance in time to the music. For further discussion of eventhood as a cultural or pragmatic construct, see Bruce (1988), Durie (1997), Enfield (2002) and (Cole 2016).

White Hmong

(19) a. nws dhia tshov qeej 3SG dance blow bamboo.pipes He dances playing the pipes.

b. * nws dhia mloog nkauj 3sG dance listen song for: He dances and listens to music. (Jarkey 1991:169-170; 2015:117)

Eventhood may be a necessary criterion for some types of SVCs (i.e. symmetrical SVCs, Section 3.1), but it is not a sufficient criterion for monoclausality, since, by any non-circular definition, a single event can be expressed by more than one clause. The most insightful approaches to eventhood in language involve methods of psycholinguistic experimentation that are beyond what can be expected of an average linguist working on a grammatical description. Since most descriptions of SVCs cannot be expected to prove eventhood, it is not a practical criterion. However, linguists should note any cases where acceptability judgments appear to be influenced by non-morphosyntactic factors 
like event construal.

\subsection{Linking or subordinating marking}

The absence of any morphosyntactic marker of subordination, coordination or complementation has been considered a feature of SVCs since Riis (1854:103) who described a “connection of sentences without any conjunction" in Akan. Hyman (1971) points out that there are constructions that appear to be identical to traditional examples of SVCs except for the presence of some type of linking morpheme. For example, the Fe'fe' consecutive construction in example 20a uses the same verbs with the same meaning as an SVC in Nupe in example 20b, only differing in that one of the verbs in the Fe'Fe' consecutive constructions is morphologically marked as a coordinated verb.

$$
\text { Fe'fe' (Niger-Congo) }
$$

a. à kà láh pǐc ncwēe mbáa he PST take knife and.cut meat He cut the meat with a knife.

Nupe (Niger-Congo)

b. ù lá èbī bā nākà he take knife cut meat He cut the meat with a knife. (Hyman 1971)

While Hyman (1971) does not suggest that these similarities undermine making a distinction between the two categories, other linguists have expanded the definition of SVCs by either assuming or arguing that the absence of a linking marker should not be criterial (e.g. Aikhenvald 2010:21; Foley 1997:382; Lord 1993:2; Shibatani 2009:256). Likewise, the label SVC is normally not used if a verb is overtly marked as a dependent or non-finite morphological form (e.g. infinitival or participle form). However, several linguists have expanded the definition of SVCs to include constructions where one verb has apparent non-finite marking (e.g. Goddard 1988; Hale 1991; Jensen 1999; 
Shibatani 2009). For example, in Korean, Li (1991:134) and others controversially treat examples like 21 as SVCs, claiming that what some view as a morphosyntactic linker, $-e$, is better analyzed as a primarily phonological phenomenon with no syntactic or semantic content.

Korean

(21) John-i Mary-lul ttaeli-e cuki-ess-ta John-NOM Mary-ACC hit-E kill-PST-DECLARATIVE

John hit Mary (and as a result) killed her. (Li 1991:116)

The expanded views of SVCs that include constructions with some type of morphosyntactic linker or non-finite verbal morphology are relatively recent proposals, and they represent a minority position in the literature. While the similarity with SVCs is clear, comparative studies can be done across categories of multiverb constructions, so there is no need to lump all functionally-similar constructions into the same category.

\section{FUNCTIONS OF SVCs}

The range of semantic concepts that SVCs can express is generally taken to be unrestricted. However, there are a number of common functions of SVCs that are repeatedly discussed in the literature. This is true regardless of what particular definition of SVC is applied, with the exception of definitions that include a semantic restriction (Section 2.1.3). Aikhenvald (2006b) describes two general types of SVCs: symmetric and asymmetric (cf. Bamgboșe 1974; Sebba 1987:40). Symmetric SVCs have no obvious restriction to a particular subclass of verbs, and the semantic interpretation is typically of two closely-associated sequential activities, sometimes with a cause-effect interpretation. In contrast, asymmetric SVCs restrict one of the verb slots in the construction to a particular class of verbs. In discussions of grammaticalization paths for verbs in SVCs, it is sometimes noted that it is the restricted verb in the asymmetric type of SVC 
that has a tendency to grammaticalize into a preposition, adverb or affix (Bowern 2008; Durie 1988; Lord 1973, 1993). Asymmetric SVCs can be roughly grouped according to the semantics of the verbs allowed in the restricted position of each construction type. Some of the most common semantic types of asymmetric SVCs are motion (Section 3.2), posture (Section 3.3), valency-changing (Section 3.4) and aspectual (Section 3.5). This short list is by no means comprehensive. More detailed overviews are given in several typologies of the functions of SVCs (e.g. Aikhenvald 2006b; George 1975; Jansen et al. 1978; van Staden and Reesink 2008; Stahlke 1970; Unterladstetter 2020; Voorhoeve 1975).

\subsection{Symmetrical}

Because symmetric SVCs do not restrict which verbs can occur in a series, it is not always clear that they can be distinguished from constructions that are called clausechaining (DeLancey 1991; Hale 1991) or asyndetic coordination. However, at least on a language-specific basis, symmetrical SVCs can be distinguished from other construction types based on the morphosyntactic criteria discussed in Section 2. There is, in principle, no limit to the number of verbs that can occur in this type of SVC. Arguments can be shared across multiple verbs in sequential SVCs with more than two verbs, as in example 22 and example 1 above.

Isu (Bantu)

(22) Tsân-Kây wíy ${ }^{\downarrow}$ mbám zùw kwè fwú nà váb k-íy kâ Tsang-Kay kill CM9.cobra skin cook chew and CM7.bone CM7-of NEG kém-á break-IPFV

Tsang-Kay killed a cobra, skinned (it), cooked (it), ate (it) without a bone getting broken. (Kießling 2011:39) 


\subsection{Motion}

Of all of the semantic types of asymmetric SVCs, motion SVCs are the most common (Aikhenvald 2006b:47; Crowley 1987:42; Durie 1997:310). Foley and Olson (1985:47) call motion verbs "the serializing verb type par excellence." There are several subtypes of motion SVCs. In the most common type of motion SVC, there is a verb that expresses a manner of motion such as 'run', 'fly' or 'jump', and a directional verb that expresses a path of motion, usually 'go' or 'come'. This is typically called a directional SVC. In a directional SVC, the directional verb is nearly always found in the second position, as in example 23 (Lovestrand and Ross 2020).

Dagaare (Niger-Congo)

(23) o da zo wa- $\varepsilon$ la

3SG PST run come-PRF FACTITIVE

She/he ran here. (Bodomo 1997:83)

Some languages allow multiple directional verbs in a single directional SVC to give more complex information about the path of motion, such as example 24 which has a general motion verb followed by three verbs specifying the path of motion.

Numbami (Oceanic)

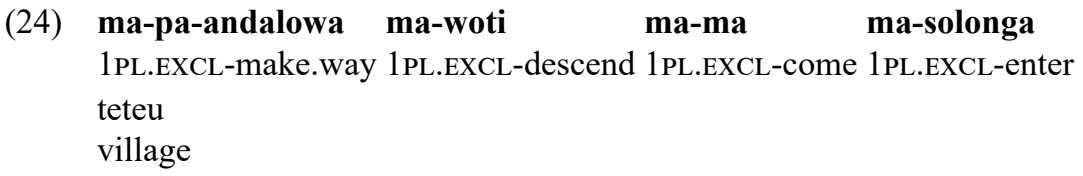

We walked down here into the village. (Bradshaw 1993:148)

In the other common type of motion SVC, a motion verb occurs before the main verb and indicates a change of location that occurs prior to the activity expressed by the main verb, as in example 25, as well as example 2 above. This can be called a prior motion SVC. The verb order in a prior motion SVCs is nearly always iconic (Lovestrand and Ross 2020). 
Dagaare (Niger-Congo)

(25) ̀̀ dà wà dí lá kàpálà

1SG PST come eat FOC fufu

I came [and] ate fufu. (Hiraiwa and Bodomo 2008:807)

\subsection{Posture}

Some languages have an SVC where one verb slot is restricted to verbs of posture and possibly other stative verbs. The activity or state expressed by the verb in the restricted position is understood to be simultaneous with that of the other verb, as in examples 26 and 27.

Avatime (Niger-Congo)

(26) o-di Đwغ̀

CM-sit drink

He sits drinking. (van Putten 2017)

Tariana (North Arawak)

(27) pi-wapa pi-wha

2sG-wait 2sG-sit

Sit [and] wait! (Aikhenvald 2006a:185)

\subsection{Valency-changing}

The most common types of valency-changing SVCs are those in which one verb in the SVC has a specialized function of introducing a certain type of semantic argument in the construction. This is most commonly an instrument, a recipient/benefactive argument, or a causer. In a few languages, there is an SVC that has the function of decreasing the number of arguments normally expressed by the main verb.

The most common type of instrumental SVC has the verb 'take' in the first position followed by the main verb, as in example 28. The object of 'take' functions as the 
semantic instrument of the activity associated with the main verb. Less common, but still frequent, are instrumental SVCs which employ a verb glossed 'use' to introduce the instrument, as in example 4 above.

\section{Gungbe (Niger-Congo)}

(28) Sćtù zé kpò ló xò Kòjó Setu take stick DET hit Kojo

Setu hit Kojo with the stick. (Aboh 2009:16-17)

Another common type of valency-increasing SVC employs the verb 'give' to introduce a benefactive or recipient argument. In these cases, the verb 'give' usually occurs in a position following the main verb. In some cases, the object of a preceding verb is physically transferred to the complement of the verb 'give', as in example 29. In other cases, the complement of 'give' is a beneficiary who does not physically receive anything, as in example 30 .

\section{Yoruba (Niger-Congo)}

(29) mo mú ìwé wá fún ẹ

I took book came gave you

I brought you a book. (Stahlke 1970:63)

Sranan (Creole)

(30) Mi feti gi mi kondre

I fight give my country

I fight for my country. (Sebba 1987)

In the most common type of causative SVC, the agent/subject of the first verb is the causer, and its patient/object is the causee and the agent/subject of the second verb. The first verb in a causative SVC might be 'make' (as in example 31), 'take' or 'give'.

Cantonese (Sino-Tibetan) 
(31) ngo $^{5}$ zing $^{2}$ keoi $^{5}$ dit $^{3}$

I make $3 \mathrm{sg}$ fall

I made him fall. (Matthews 2006:75)

There are also SVCs that have a valency-reducing function. It appears that this type of construction is mainly found in Southeast Asia. In example 32, the use of the verb toka (which elsewhere means 'touch') creates a passive-like construction in Kristang, a Portuguese creole spoken in Malaysia. Similar constructions occur in Thai (Thepkanjana 1986:100), Lao (Enfield 2008:171-173) and Hmong (Creswell and Snyder 2000).

Kristang (Creole)

(32) aké pesi ja toka kumí di gatu that fish PRF touch eat SOURCE cat

The fish got eaten by the cat. (Baxter 1988:211)

\subsection{Aspectual}

In aspectual SVCs (also called auxiliary or modal SVCs), one of the verbs in the construction has a grammaticalized or "bleached" meaning which often falls into one of the major types of tense, aspect or mood categories. For example, a verb glossed 'finish' is commonly found to express perfect or completive aspect in an aspectual SVC, as in examples 33 and 34 .

\section{Ewe (Niger-Congo)}

\section{(33) me-dui vo}

1sG-eat finish

I have eaten it up. (Westermann 1930)

Yabem (Austronesian)

(34) bôc saleyna sey aêàcma jangom gê-bacné pig bush-of 3sG.eat 1PL-GEN maize 3sG-finish.up

The forest pigs ate up our maize. (Dempwolff 1939; glosses from Bradshaw 1982:27) 
It is also common to find a verb that has a meaning like 'sit', 'stay' or 'live (somewhere)' outside of an SVC, but expresses continuous or progressive meaning in an SVC, as in example 35 , as well as example 5 above.

Yatye (Niger-Congo)

(35) òdìde ahyẹ ibí ìtywi man squat come home

The man is coming home. (Stahlke 1970:65)

\section{SVCS IN GENERATIVE SYNTAX}

Recent overviews of Chomskyan analyses of SVCs include Jensen (2014:186-191), Cleary-Kemp (2015:223-229) and Cole (2016). The core issue in this approach is the relationship between the verbs in an SVC and their arguments. Any generative approach to syntax includes a mechanism by which a verb must be matched with its arguments and determine their semantic roles. When SVCs involve argument sharing (Section 2.2.3), there appear to be an insufficient number of arguments for the number of verbs. Various strategies have been proposed to account for this.

Schachter (1974) proposes treating SVCs as concatenated verb phrases licensed by a special phrase structure rule. Along similar lines, Baker (1989) is an influential (though frequently criticized) proposal in which a special double-headed verb phrase allows two verbs in an object-sharing SVC to "theta-mark" the single object. ${ }^{7}$ Hiraiwa and Bodomo (2008) offer an alternative approach in which the verbs of an SVC are in separate constituents, but the shared object is the constituent of more than one verb phrase.

Other linguists have proposed analyses that do not require a special type of syntactic structure just for SVCs. This is generally done by assuming the existence of a null pronominal element (e.g. Agbedor 1994; Byrne 1985; Campbell 1996; Carstens 2002;

\footnotetext{
${ }^{7}$ For criticism see Byrne (1991), Collins (1997), Durie (1997) and Aboh (2009) inter alia.
} 
Collins 1997; Larson 1991; Veenstra 1993). Baker and Stewart (2002) propose a mixed account, in which some types of SVCs are assumed to have a null pronominal, and others are not. More recent Chomskyan analyses have been proposed by Jensen (2014:201217) for Jarai, Cleary-Kemp (2015:228-229, 245) for Koro and Cole (2016:134-141) for Lao.

In addition to the above "syntactic" analyses, Lefebvre (1991) proposes a "lexical" analysis for all types of 'take' serialization in Fon (Niger-Congo). Lefebvre proposes that these constructions should be described as operations on the lexical semantics of verbs. ${ }^{8}$ Aboh (2009:30) agrees that such an analysis is required in order to account for SVCs, and that it is an "illusion that SVCs involve lexical verbs that must discharge their respective $\theta$-roles."

Outside of Chomskyan syntax, in constraint-based generative theories, most authors have assumed a syntactic mechanism for combining verbs in an SVC. For example, this is the approach of the Lexical-Functional Grammar (LFG) accounts of SVCs in Dagaare by Bodomo (1997) and of SVCs in Tariana by Andrews and Manning (1993), as well as the Head-Driven Phrase Structure account of Mandarin SVCs by Müller and Lipenkova (2009). In contrast, Lovestrand (2018) proposes an LFG analysis of Barayin SVCs in which the restricted verb is polysemous - one of its meanings allowing it to combine with another verb.

Where generative analyses of SVCs purport to be applicable universally, they tend to restrict the definition of SVCs depending on which constructions fit the proposed analysis. This creates controversy with linguists who have a different perspective on how to delimit the data. The disagreement cannot be resolved since there are few if any objective grounds for claims that one feature or another must be criterial in the definition of SVCs. It is unclear whether the resulting categories of constructions can be said to be proper objects of cross-linguistic comparison.

\footnotetext{
${ }^{8}$ See Baker (1991:88-89) for criticism.
} 


\section{SVCS IN COMPARATIVE SYNTAX}

From a descriptive perspective, the conceptual and empirical variation outlined in Section 2 is unproblematic in so far as each linguist can focus on the details of the language being described, and define their terminology clearly in order to avoid misinterpretations. From a comparative perspective, it is reasonable to ask to whether it is possible to make generalizations about constructions that are defined and diagnosed by different criteria in each language.

Haspelmath (2016) claims that it is not possible, and instead proposed a significantly restricted definition of SVCs as a "comparative category". Comparative categories are defined by linguists for the purpose of making cross-linguistic generalizations. They are not natural kinds to be discovered. Only language-specific "descriptive categories" can be discovered by analysis. This means that "linguists should feel free to simply advance a definition and then work with it. If the resulting work turns out to be interesting and productive, then the definition has proved useful" (Haspelmath 2016:293).

Arbitrarily restrictive approaches to defining SVCs can be very useful for quantitative cross-linguistic studies (e.g. Lovestrand and Ross 2020; Ross 2020). However, besides the problem of arbitrariness, another shortcoming of restrictive approaches is that they ignore those SVC-like constructions that fail to meet one or more of the criteria. These excluded constructions fall into a typological gap between some restricted definition of SVCs and any other well-defined category of multiverb constructions. This is not an effective way to provide a comprehensive understanding of all of the empirical variation found in multiverb constructions.

Other linguists have proposed a more inclusive approach to defining SVCs which is sometimes described as a prototype approach. For example, Aikhenvald (2006b:3) states that "in an individual language, SVCs are expected to have most, but not necessarily all, of these properties. This suggests a scalar, or continuum-type, approach to SVC — which can be either more or less like the prototype - which has maximal prop- 
erties." This is a useful approach for cases where not all criteria are diagnosable in a particular language. It is also a practical way to make broad generalizations across languages (as in Section 3) without rigorously testing the properties of every putative SVC.

However, the prototype approach cannot be used for precise quantitative crosslinguistic studies, unless it is made explicit which criteria are optional and how that optionality is accounted for quantitatively. ${ }^{9}$ Even if it is made explicit, Bickel (2007:247) suggests that such an approach would still be subject to bias: "There remains a sense of arbitrariness in such definitions, and, worse, a sense that those languages which happen to be studied by the most widely read linguists end up closest to the universal definition (often then said to provide the "prototype" of the phenomenon)."

Bickel $(2007,2010)$ instead proposes the "multivariate approach". The multivariate approach aims "to decompose terms like 'cosubordination' [and 'serialization'] into sets of variables that capture all dimensions in which any given pair of structures may be identical or different - whether between languages or within languages" (Bickel 2010:55; my addition in brackets). The multivariate approach is a bottom-up, inductive approach to comparative linguistics. The method is to quantify the distribution and correlations of fine-grained and easily-diagnosable features of morphosyntax independently of larger categories like SVC that bundle several features together. Statistical analyses are then applied to determine whether there are any natural clusters of features that justify such categories.

No multivariate analysis of SVCs has been done yet, but Unterladstetter (2020) presents the kind of fine-grained variables necessary for developing a multivariate analysis in a comparison of SVCs in 32 languages of eastern Indonesia. Part of the study quantifies how often a particular grammatical feature is found across different semantic types of SVCs. For example, in regards to argument sharing (Section 2.2.3), 300 of 301 instances of prior motion SVCs (Section 3.2) have the property of sharing the "same

\footnotetext{
${ }^{9}$ As in, for example, Canonical Typology (Brown et al. 2013).
} 
subject" whereas for directional SVCs the argument sharing patterns are much more varied (Unterladstetter 2020:300; see also Lovestrand and Ross 2020). However, in regards to verbal inflection patterns and contiguity, the morphosyntactic properties do not clearly distinguish these two semantic types. This type of approach to comparing SVCs cross-linguistically has the potential to ground the categorization of multiverb constructions in quantitative data.

\section{CONCLUSION}

For linguists describing the grammar of a particular language, SVCs represent a significant challenge. Section 2 makes clear that there are many morphosyntactic and semantic features that can be relevant to understanding SVCs (or a similar type of multiverb construction) in any given language. This means that there are many analytical prerequisites to describing SVCs, such as those listed by Aikhenvald (2018:250-254). Despite the complexity, it is certainly possible to describe SVCs, and, in some languages, a detailed description of SVCs can be central to understanding how speakers use the language.

Descriptions of SVCs in particular languages can be informed by typological studies, both of the comparative concept approach and of the prototype approach (Section 5). However, a more general typology of multiverb constructions, including SVCs, is a work in progress. Linguists should not limit themselves to the concepts provided by typologists, and should pay special attention to constructions that do not fit the current conceptualizations of SVCs. More detailed descriptions of SVCs and other types of multiverb constructions are needed to inform our understanding of how verbs blur the lines of clausehood in languages all over the world.

One thing that is clear from the literature on SVCs is that traditional notions of complex sentences based predominately on studies of European languages are inadequate from a more universal perspective, but this problem is not repaired by the misleading 
overgeneralization of lumping the diverse types of multiverb constructions into a handful of categories such as SVC, clause-chaining (Foley 2010), co-subordination (Bickel 2010), converb constructions (Haspelmath 1995) and consecutive constructions (Hyman 1971). There are many more degrees and layers of interclausal cohesion than have been explicitly accounted for. Further research into the myriad ways that languages combine verbs is a significant opportunity for refining our understanding of the nature of clausehood, both from a general comparative perspective (Section 5) and in generative approaches to syntactic analysis (Section 4). This area of research has the potential to provide an empirically-informed grounding of our intuitive notion of the clause as a fundamental and universal concept in syntax, as well as to provide further insights into how events are conceptualized in grammar.

\section{DISCLOSURE STATEMENT}

The author is not aware of any affiliations, memberships, funding, or financial holdings that might be perceived as affecting the objectivity of this review.

\section{ACKNOWLEDGMENTS}

The majority of the research for this paper was done while the author was a recipient of the Basant Kumar and Sarala Birla Graduate Studentship at the University of Oxford. The dissertation much of this work is based on was supervised by Mary Dalrymple and examined by Ash Asudeh and Peter Austin. Thanks to Xavier Bach, Willem Burung, Stephen Jones, Soung-U Kim, Daniel Ross, Carla Unseth, Volker Unterladstetter and John B. Walker for feedback on earlier drafts of this paper. Thanks also to an anonymous reviewer for their constructive input. Naturally, any remaining faults are my own. 


\section{References}

Aboh, Enoch Oladé (2009). Clause structure and verb series. Linguistic Inquiry, 40(1):1-33.

Agbedor, Paul (1994). Verb serialization in Ewe. Nordic Journal of African Studies, 3(1):115-135.

Aikhenvald, Alexandra Y. (1999). Serial constructions and verb compounding: Evidence from Tariana (North Arawak). Studies in Language, 23(3):469-497.

Aikhenvald, Alexandra Y. (2006a). Serial verb constructions in Tariana. In Aikhenvald, Alexandra Y. and Dixon, Robert M.W., editors, Serial Verb Constructions: A Crosslinguistic Typology, pages 178-201. Oxford University Press, Oxford; New York.

Aikhenvald, Alexandra Y. (2006b). Serial verb constructions in typological perspective. In Aikhenvald, Alexandra Y. and Dixon, Robert M. W., editors, Serial verb constructions: A cross-linguistic typology, pages 1-68. Oxford University Press, Oxford; New York.

Aikhenvald, Alexandra Y. (2010). Multi-verb constructions: Setting the scene. In Aikhenvald, Alexandra Y. and Muysken, Pieter, editors, Multi-verb Constructions: A View from the Americas, pages 1-26. Brill.

Aikhenvald, Alexandra Y. (2018). Serial verbs. Oxford studies in typology and linguistic theory. Oxford University Press, New York, NY.

Aikhenvald, Alexandra Y. and Dixon, Robert M. W., editors (2006). Serial verb constructions: A cross-linguistic typology. Oxford University Press, Oxford, U.K. ; New York.

Ameka, Felix K (2001). Multiverb constructions in a West African areal typological perspective. unpublished manuscript. 
Ameka, Felix K (2005). Multiverb constructions on the West African littoral: Microvariation and areal typology. In Grammar and beyond: Essays in honour of Lars Hellan, pages $15-42$. Novus.

Anderson, Gregory D.S. (2006). Auxiliary verb constructions. Oxford University Press, Oxford.

Andrews, Avery and Manning, Christopher (1993). Information spreading and levels of representation in $L F G$. Technical Report 176. CSLI Publications.

Ansre, Gilbert (1966). The verbid - A caveat to 'serial verbs'. Journal of West African Languages, 3(1):29-32.

Baird, Louise (2008). Motion serialisation in Keo. In Senft, Gunter, editor, Serial verb constructions in Austronesian and Papuan languages, pages 55-74. Australian National University, Canberra.

Baker, Mark (1989). Object sharing and projection in serial verb constructions. Linguistic Inquiry, 20(4):513-553.

Baker, Mark (1991). On the relation of serialization to verb extensions. In Lefebvre, Claire, editor, Serial Verbs: Grammatical, Comparative and Cognitive Approaches, pages 79-102. John Benjamins, Amsterdam.

Baker, Mark and Stewart, Osamuyimen T. (2002). A serial verb construction without constructions. unpublished manuscript, Rutgers University.

Balmer, W.T. and Grant, F.C.F. (1929). A grammar of the Fante-Akan language. Atlantis Press, London.

Bamgboșe, Ayọ (1974). On serial verb constructions and verbal status. Journal of West African Languages, 9(1):17-48. 
Banjo, Ayo (1974). Sentence negation in Yoruba. Studies in African Linguistics, Supplement 5:35-47.

Baxter, Alan N (1988). A grammar of Kristang (Malacca Creole Portuguese). Pacific Linguistics, Canberra.

Bendix, Edward H. (1972). Serial verbs in the Caribbean and West Africa: Their semantic analysis in Papiamento. unpublished manuscript, Hunter College of the City University of New York.

Benedicto, Elena, Cvejanov, Sandra, Quer, Josep, et al. (2008). The morphosyntax of verbs of motion in serial constructions: A crosslinguistic study in three signed languages.

Bickel, Balthasar (2007). Typology in the 21st century: Major current developments. Linguistic Typology, 11(1):239-251.

Bickel, Balthasar (2010). Capturing particulars and universals in clause linkage: A multivariate approach. In Bril, Isabelle, editor, Clause linking and clause hierarchy: Syntax and pragmatics, pages 51-101. John Benjamins, Amsterdam.

Bisang, Walter (1991). Verb serialization, grammaticalization and attractor positions in Chinese, Hmong, Vietnamese, Thai and Khmer. In Seiler, Hansjakob and Premper, Waldfried, editors, Partizipation: Das sprachliche Erfassen von Sachverhalten, pages 509-562.

Bisang, Walter (2009). Serial verb constructions. Language and Linguistics Compass, 3(3):792-814.

Bodomo, Adams. (1997). Paths and pathfinders: Exploring the syntax and semantics of complex verbal predicates in Dagaare and other languages. $\mathrm{PhD}$ dissertation, Norwegian University of Science and Technology. 
Bohnemeyer, Jürgen, Enfield, Nicholas J, Essegbey, James, Ibarretxe-Antuñano, Iraide, Kita, Sotaro, Lüpke, Friederike, and Ameka, Felix K (2007). Principles of event segmentation in language: The case of motion events. Language, pages 495-532.

Bos, Heleen F. (2016). Serial verb constructions in Sign Language of the Netherlands. Sign Language \& Linguistics, 19(2):238-251.

Bowern, Claire (2008). The diachrony of complex predicates. Diachronica, 25(2):161185.

Bradshaw, Joel (1982). Word order change in Papua New Guinea Austronesian languages. PhD dissertation, University of Hawaii.

Bradshaw, Joel (1993). Subject relationships within serial verb constructions in Numbami and Jabêm. Oceanic Linguistics, pages 133-161.

Bril, Isabelle and Ozanne-Rivierre, Françoise (2004). Complex predicates in Oceanic languages: Studies in the dynamics of binding and boundness. Walter de Gruyter, Berlin.

Brown, Dustan, Chumakina, Marina, and Corbett, Greville G., editors (2013). Canonical morphology and syntax. Oxford University Press.

Bruce, Les (1988). Serialization: From syntax to lexicon. Studies in Language, 12(1):19-49.

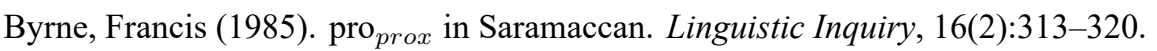

Byrne, Francis (1991). Approaches to "missing" internal (and external) arguments in serial structure: Some presumed difficulties. In Byrne, Francis and Huebner, Thom, editors, Development and Structures of Creole Languages, pages 207-222. John Benjamins. 
Campbell, Richard (1996). Serial verbs and shared arguments. Linguistic Review, 13(2):83-118.

Carstens, Vicki (2002). Antisymmetry and word order in serial constructions. Language, 78(1):3-50.

Christaller, Johann Gottlieb (1875). A grammar of the Asante and Fante language called Tshi [Chwee, Twi] based on the Akuapem dialect with reference to the other (Akan and Fante) dialects. Basel Evangelical Mission Society, Basel.

Cleary-Kemp, Jessica (2015). Serial Verb Constructions Revisited: A Case Study from Koro. $\mathrm{PhD}$ dissertation, University of California, Berkeley.

Cole, Douglas (2016). Lao serial verb constructions and their event representations. Ph.D. dissertation, University of Iowa.

Collins, Chris (1997). Argument sharing in serial verb constructions. Linguistic Inquiry, 23(3):461-497.

Comrie, Bernard (1995). Serial verbs in Haruai (Papua New Guinea) and their theoretical implications. In Bouscaren, Janine and Culioli, Antoine, editors, Langues et langage: Problèmes et raisonnement en linguistique; mélanges offerts à Antoine Culioli, pages 25-38. Presses Univ. de France, Paris.

Conrad, Robert J and Wogiga, Kepas (1991). An outline of Bukiyip grammar. Pacific Linguistics, Canberra.

Couvee, Sascha and Pfau, Roland (2018). Structure and Grammaticalization of Serial Verb Constructions in Sign Language of the Netherlands-A Corpus-Based Study. Frontiers in Psychology, 9:993.

Creswell, Cassandre and Snyder, Kieran (2000). Passive and passive-like constructions in Hmong. In Billerey, Roger and Lillehaugen, Brook Danielle, editors, WCCFL 19: Proceedings of the 19th West Coast Conference on Formal Linguistics, pages 71-82. 
Crowley, Terry (1987). Serial verbs in Paamese. Studies in Language, 11(1):35-84.

Crowley, Terry (2002). Serial verbs in Oceanic: A descriptive typology. Oxford University Press, Oxford/New York.

Davidson, Donald (1967). The logical form of action sentences. In Rescher, Nicholas, editor, The logic of decision and action, pages 81-95. University of Pittsburgh Press.

Déchaine, Rose-Marie (1993). Serial verb constructions. In Jacobs, Joachim, von Stechow, Arnim, and Vennemann, Theo, editors, Syntax: Ein internationales Handbuch zeitgenössischer Forschung = An international handbook of contemporary research, pages 799-825. Walter de Gruyter, Berlin; New York.

Defina, Rebecca (2016). Do serial verb constructions describe single events?: A study of co-speech gestures in Avatime. Language, 92(4):890-910.

Defina, Rebecca and Majid, Asifa (2012). Conceptual event units of putting and taking in two unrelated languages. In Proceedings of the 34th Annual Meeting of the Cognitive Science Society (CogSci 2012). Cognitive Science Society, Austin, TX.

DeLancey, Scott (1991). The origins of verb serialization in Modern Tibetan. Studies in Language, 15(1):1-23.

Dempwolff, Otto (1939). Grammatik der Jabem-Sprache auf Neuguinea. Friederichsen, de Gruyter, Hamburg.

Dempwolff, Otto (2005). Otto Dempwolff's Grammar of the Jabem language in New Guinea (Bradshaw, J. and Czobor, F., Trans.). University of Hawai'i Press, Honolulu.

Durie, Mark (1988). Verb serialization and "verbal-prepositions" in Oceanic languages. Oceanic linguistics, pages 1-23.

Durie, Mark (1997). Grammatical structures in verb serialization. In Alsina, Alex, 
Bresnan, Joan, and Sells, Peter, editors, Complex predicates, pages 289-354. CSLI Publications, Stanford.

Enfield, N.J. (2002). Cultural logic and syntactic productivity: Associated posture constructions in Lao. In Enfield, N.J., editor, Ethnosyntax, pages 231-258. Oxford University Press, Oxford.

Enfield, N.J. (2008). Verbs and multi-verb constructions in Lao. In Diller, A.V., Edmondson, J.A., and Luo, Y., editors, The Tai-Kadai Languages, pages 83-183. Routledge, London.

Enfield, N.J. (2009). Review of the book Serial verb constructions: A cross-linguistic typology ed. by Alexandra Y. Aikhenvald and R. M. W. Dixon. Language, 85(2):445451.

Essegbey, James (2004). Auxiliaries in serialising languages: On COME and GO verbs in Sranan and Ewe. Lingua, 114(4):473-494.

Evans, Nicholas D (1995). A grammar of Kayardild: With historical-comparative notes on Tangkic, volume 15. Walter de Gruyter.

Filbeck, David (1975). A grammar of verb serialization in Thai. In Harris, J.G. and Chamberlain, J.R., editors, Studies in Tai linguistics in honor of William J. Gedney, pages 112-129. Central Institute of English Language.

Foley, William A. (1997). Polysynthesis and complex verb formation: The case of applicatives in Yimas. In Alsina, Alex, Bresnan, Joan, and Sells, Peter, editors, Complex predicates, pages 355-395. CSLI Publications, Stanford.

Foley, William A. (2008). The notion of 'event' and serial verb constructions: Arguments from New Guinea. In Khanittanan, Wilaiwan and Sidwell, Paul, editors, Papers from the 14th meeting of the Southeast Asian Linguistics Society 2004, pages $129-156$. 
Foley, William A. (2010). Clause linkage and nexus in Papuan languages. In Bril, Isabelle, editor, Clause Linking and Clause Hierarchy: Syntax and Pragmatics, pages 27-50. John Benjamins, Amsterdam.

Foley, William A. and Olson, Mike (1985). Clausehood and verb serialization. In Nichols, Johanna and Woodbury, Anthony C, editors, Grammar inside and outside the clause, pages 17-60. Cambridge University Press, Cambridge.

François, Alexandre (2006). Serial verb constructions in Mwotlap. In Aikhenvald, Alexandra Y. and Dixon, Robert M. W., editors, Serial verb constructions: A crosslinguistic typology, pages 223-238. Oxford University Press, Oxford; New York.

George, Isaac (1975). Typology of verb serialization. Journal of West African Languages, 10(1):78-97.

Givón, Talmy (1991). Serial verbs and the mental reality of "event": Grammatical vs. cognitive packaging. In Traugott, Elizabeth Closs and Heine, Bernd, editors, Approaches to grammaticalization, pages 81-128. John Benjamins, Amsterdam/Philadelphia.

Goddard, Cliff (1988). Verb serialisation and the circumstantial construction in Yankunytjatjara. In Austin, Peter, editor, Complex Sentence Constructions in Australian Languages, Typological Studies in Language, pages 177-192. John Benjamins.

Green, Rebecca (1995). A grammar of Gurr-goni. PhD dissertation, Australian National University.

Guillaume, Antoine (2013). Algunas reflexiones sobre las construcciones de verbos seriales 'continguas e incoporantes' y el sistede movimiento asociado en cavineña. In Ospina Bozzi, A.M., editor, Expresión de nociones espaciales en lenguas amazónicas, pages 17-37. Instituto Caro y Cuervo, Bogotá. 
Hale, Ken (1991). Misumalpan verb sequencing constructions. In Lefebvre, Claire, editor, Serial verbs: Grammatical, comparative and cognitive approaches, pages 1-35. John Benjamins, Amsterdam.

Haspelmath, Martin (1995). The converb as a cross-linguistically valid category. In Haspelmath, Martin and König, Ekkehard, editors, Converbs in cross-linguistic perspective, pages 1-55. Mouton de Gruyter, Berlin; New York.

Haspelmath, Martin (2016). The serial verb construction: Comparative concept and cross-linguistic generalizations. Language and Linguistics, 17(3):291-319.

Hiraiwa, Ken and Bodomo, Adams (2008). Object-sharing as symmetric sharing: Predicate clefting and serial verbs in Dàgáárè. Natural Language \& Linguistic Theory, 26(4):795-832.

Hyman, Larry M. (1971). Consecutivization in $\mathrm{Fe}^{\text {?fe? }}$. Journal of African Languages, $10(2): 29-43$.

Jansen, Bert, Koopman, Hilda, and Muysken, Pieter (1978). Serial verbs in the Creole languages. Amsterdam Creole Studies, 2:125-159.

Jarkey, Nerida (1991). Serial verbs in White Hmong: A functional approach. $\mathrm{PhD}$ dissertation, University of Sydney.

Jarkey, Nerida (2015). Serial verbs in White Hmong. Brill.

Jensen, Cheryl (1999). Tupí-Guaraní. In Dixon, R.M.W. and Aikhenvald, Alexandra, editors, The Amazonian languages, pages 125-163. Cambridge University Press, Cambridge.

Jensen, Joshua (2014). Jarai clauses and noun phrases syntactic structures in an Austronesian language. De Gruyter Mouton. 
Kießling, Roland (2011). Verbal serialisation in Isu (West-Ring) - a Grassfields language of Cameroon. Köppe, Köln.

Lambert-Brétière, Renée (2010). Séries verbales: Le critère de la négation revisité. In Floricic, Frank and Lambert-Brétière, Renée, editors, La négation et les énoncés non susceptibles d'être niés, pages 211-223. Éditions du CNRS, Paris.

Landau, Idan (2000). Elements of Control: Structure and Meaning in Infinitival Constructions. Springer Science \& Business Media, Dordrecht.

Larson, Richard K. (1991). Some issues in verb serialization. In Lefebvre, Claire, editor, Serial Verbs: Grammatical, comparative and cognitive approaches, pages 185-211. John Benjamins, Amsterdam; Philadelphia.

Lefebvre, Claire (1991). Take serial verb constructions in Fon. In Lefebvre, Claire, editor, Serial Verbs: Grammatical, Comparative and Cognitive Approaches, pages 37-78. John Benjamins, Amsterdam.

Li, Charles N. and Thompson, Sandra A. (1973). Serial verb constructions in Mandarin Chinese: Co-ordination or subordination? In You Take the High Node and I'll Take the Low Node: Papers from the Comparative Syntax Festival, pages 96-103, Chicago. Chicago Linguistic Society.

Li, Charles N. and Thompson, Sandra A. (1974). Co-verbs in Mandarin Chinese: Verbs or prepositions? Journal of Chinese Linguistics, 2(3):257-278.

Li, Yafei (1991). On deriving serial verb constructions. In Lefebvre, Claire, editor, Serial Verbs: Grammatical, Comparative and Cognitive Approaches, pages 103-35. John Benjamins, Amsterdam.

Lord, Carol (1973). Serial verbs in transition. Studies in African Linguistics, 4(3):269296. 
Lord, Carol (1975). Igbo verb compounds and the lexicon. Studies in African linguistics, 6(1):23.

Lord, Carol (1993). Historical change in serial verb constructions, volume 26 of Typological studies in language. John Benjamins, Amsterdam/Philadelphia.

Lovestrand, Joseph (2018). Serial verb constructions in Barayin: Typology, description and Lexical-Functional Grammar. PhD dissertation, University of Oxford.

Lovestrand, Joseph and Ross, Daniel (2020). Serial verb constructions and motion semantics. In Jacques, Guillaume and Koch, Harold, editors, Proceedings from the ALT17 workshop on associated motion, Empirical Approaches to Language Typology. de Gruyter Mouton.

Matthews, Stephen (2006). On serial verb constructions in Cantonese. In Aikhenvald, Alexandra Y. and Dixon, Robert M. W., editors, Serial verb constructions: A crosslinguistic typology, pages 69-87. Oxford University Press, Oxford; New York.

Müller, Stefan and Lipenkova, Janna (2009). Serial verb constructions in Chinese: An HPSG account. In Müller, Stefan, editor, Proceedings of the 16th International Conference on Head-Driven Phrase Structure Grammar, pages 234-254, Stanford. CSLI Publications.

Muysken, Pieter and Veenstra, Tonjes (2006). Serial verbs. In Everaert, Martin and van Riemsdijk, Henk, editors, The Blackwell Companion to Syntax, volume 4, page 234-270. Blackwell, Oxford.

Nishiyama, Kunio (1998). V-V compounds as serialization. Journal of East Asian Linguistics, 7(3):175-217.

Nordlinger, Rachel and Sadler, Louisa (2004). Nominal tense in crosslinguistic perspective. Language, pages 776-806. 
van Putten, Saskia (2017). Motion in serializing languages revisited: The case of Avatime. STUF - Language Typology and Universals, 70:303-329.

Riis, Hans Nicolaus (1853). Elemente des Akwapim-Dialects der Odschi-Sprache, enthaltend grammatische Grundzüge und Wörtersammlung nebst Sammlung von Sprüchwörten der Eingeborem. Bahnmaier, Basel.

Riis, Hans Nicolaus (1854). Grammatical outline and vocabulary of the Oji-language, with especial reference to the Akwapim-dialect, together with a collection of proverbs of the natives. Bahnmaier, Basel.

Ross, Daniel (2020). Pseudocoordination, Serial Verb Constructions and Multi-Verb Predicates: The Relationship between Form and Structure. Ph.D. dissertation, University of Illinois at Urbana-Champaign.

Schachter, Paul (1974). A non-transformational account of serial verbs. Studies in African Linguistics, Supplement 5:253-270.

Sebba, Mark (1987). The syntax of serial verbs: An investigation into serialisation in Sranan and other languages. John Benjamins, Amsterdam; Philadelphia.

Seuren, Pieter A.M. (1990). Serial verb constructions. In Joseph, Brian D. and Zwicky, Arnold M., editors, When verbs collide: Papers from the Ohio State Mini-Conference on Serial Verbs, pages 14-32. Ohio State University.

Shibatani, Masayoshi (2009). On the form of complex predicates: Toward demystifying serial verbs. In Helmbrecht, Johannes, editor, Form and function in language research, pages 309-336. Mouton de Gruyter, Berlin.

Shluinsky, Andrey (2017). An intragenetic typology of Kwa serial verb constructions. Linguistic Typology, 21(2):333-385. 
van Staden, Miriam and Reesink, G. (2008). Serial verb constructions in a linguistic area. In Senft, Gunter, editor, Serial verb constructions in Austronesian and Papuan languages, pages 17-54. Australian National University, Canberra.

Stahlke, Herbert (1970). Serial verbs. Studies in African Linguistics, 1:60-99.

Stewart, John (1963). Some restrictions on objects in Twi. Journal of African Languages, 2(2):145-149.

Supalla, Ted (1990). Serial verbs of motion in ASL. In Fischer, S.D. and Siple, P., editors, Theoretical issues in sign language research, volume 1, pages 127-152. University of Chicago Press Chicago.

Tallman, Adam J. R. (2020). Beyond grammatical and phonological words. Language and Linguistics Compass, 14(2).

Thepkanjana, Kingkarn (1986). Serial verb constructions in Thai. PhD dissertation, University of Michigan.

Unterladstetter, Volker (2020). Multi-verb constructions in Eastern Indonesia. Studies in Diversity Linguistics. Language Science Press, Berlin.

Van den Berg, René and Bachet, Peter (2006). Vitu grammar sketch. SIL.

Veenstra, Tonjes (1993). Serial verb constructions, parameter settings and thematic restrictions on argument sharing. Linguistics in the Netherlands, 10(1):153-164.

Voorhoeve, Jan (1975). Serial verbs in Creole. unpublished paper presented at the Hawaii Pidgin and Creole conference.

Welmers, William (1973). African language structures. University of California Press, Berkeley.

Welmers, William Everett (1946). A Descriptive Grammar of Fanti. Language, $22(3): 3-78$. 
Westermann, Dietrich (1907). Grammatik der Ewe-Sprache. Dietrich Reimer, Berlin.

Westermann, Dietrich (1930). A study of the Ewe language. Oxford University Press, London.

Zimmermann, Johann (1858). A grammatical sketch of the Akra- or Gã-language, with some specimens of it from the mouth of the natives and a vocabulary of the same, with an appendix on the Adanme dialect, volume 1. J.F. Steinkopf for the Basel Missionary Society, Stuttgart.

Zwicky, Arnold (1990). What are we talking about when we talk about serial verbs? In Joseph, Brian D and Zwicky, Arnold M, editors, When verbs collide: Papers from the Ohio State Mini-Conference on Serial Verbs, pages 1-13. Ohio State University. 